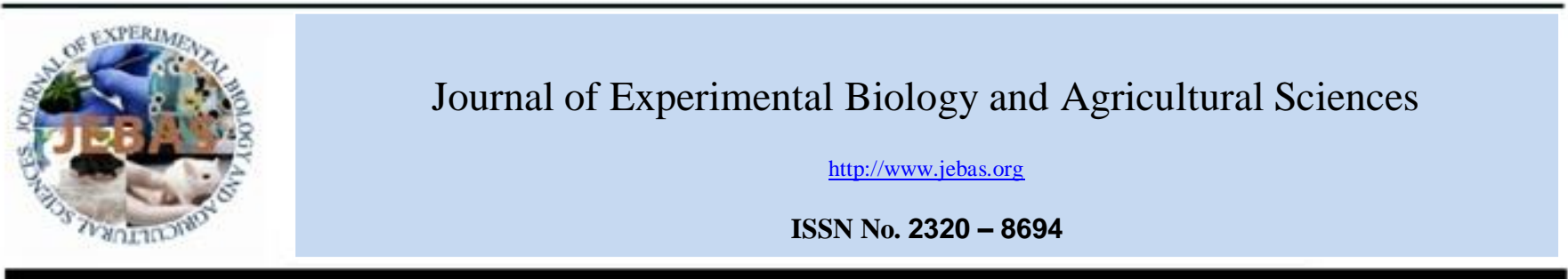

\title{
BENEFICIAL IMPACTS OF CHOLINE IN ANIMAL AND HUMAN WITH SPECIAL REFERENCE TO ITS ROLE AGAINST FATTY LIVER SYNDROME
}

\author{
Muhammad Saeed ${ }^{1}$, Mahmoud Alagawany ${ }^{2 *}$, Muhammad Asif Arain ${ }^{1}$, Mohamed Ezzat Abd \\ El-Hack ${ }^{2}$, Kuldeep Dhama ${ }^{3}$
}

${ }^{1}$ College of Animal Science and Technology, NW A \& F University, Yangling, Shaanxi, 712100 China

${ }^{2}$ Poultry Department, Faculty of Agriculture, Zagazig University, Zagazig 44511, Egypt

${ }^{3}$ Division of Pathology, ICAR-Indian Veterinary Research Institute, Izatnagar, Bareilly, 243 122, Uttar Pradesh, India

Received - September 27, 2017; Revision-October 25, 2017; Accepted - October 28, 2017

Available Online - October 31, 2017

http://dx.doi.org/10.18006/2017.5(5).589.598

KEYWORDS
Choline
Micronutrient
Fatty liver syndrome
Body fat
Human
Poultry

\begin{abstract}
Choline exists in feed ingredients and also synthesized in the body. It is essential for the physiological functions such as performance and lowering liver and body fat. If choline is insufficient in the diet, the liver fat content and abdominal fat content increase causing a metabolic disorder known as a fatty liver syndrome. Thus, dietary supplementation of choline as synthetic choline chloride or through natural herbs to the diets is compulsory. Besides fatty liver syndrome, choline deficiency causes loss of hepatocytes, heart diseases, bone and growth development abnormalities and impairment in kidney functions. The main indication of choline deficiency is raised up the level of liver enzymes like alanine transaminase (ALT). This ALT is usually measured clinically during diagnostic evaluation of hepatocellular injury to fix liver health. Lipotropic nutrients like choline could prevent fatty liver disorders through several mechanisms, such as increased hepatic very low-density lipoproteins (VLDL) secretion. Human and animal studies have reported protective impacts of choline for fatty liver disease (FLD) in addition to coronary heart disease (CVD) prevention from epidemiological data. Nowadays, choline supplementation is below the dietary recommendations because of a lack of understanding the importance of this vital nutrient for human and animal health. In the current review article, literature
\end{abstract}

* Corresponding author

E-mail: dr.mahmoud.alagwany@gmail.com (Mahmoud Alagawany)

Peer review under responsibility of Journal of Experimental Biology and Agricultural Sciences.

Production and Hosting by Horizon Publisher India [HPI] (http://www.horizonpublisherindia.in/).

All rights reserved.
All the article published by Journal of Experimental Biology and Agricultural Sciences is licensed under a Creative Commons Attribution-NonCommercial 4.0 International License Based on a work at www.jebas.org.

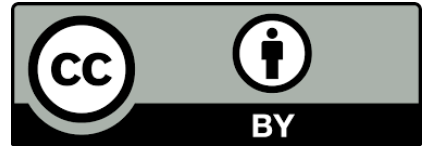


showed that choline can be considered as a powerful lipotropic agent that should be used as commercial feedadditive to cope the metabolic disorder like fatty liver syndrome in poultry, exclusively in layers reared in cages and thus replaced synthetic medicine that being used against fatty liver syndrome.

\section{Introduction}

Choline is a water-soluble micronutrient. Sometimes, it is classified among vitamins like vitamin B group and defined as a natural compound (Alagawany et al., 2016). But, it is not related to vitamins and considered as an essential nutrient due to destined much nutritional value. Currently, choline has got great importance in the last years because it can prevent liver fattening, support brain development and play a crucial role in the neural conduction. Choline has an essential role in the synthesis of betalipoproteins and phospholipids. It enables the transportation and burning of fats, which are also associated with its preventive effect against the fatty liver disorder. In some experimental animal models, choline deficiency caused liver fattening and loss of hepatocytes heart-related diseases, bone development abnormalities and impaired kidney functions (Biswas \& Giri, 2015). In poultry industry, nutrition represents about $70 \%$ of total costs, thus constitutes are a key factor in poultry production. Choline is classified as an essential vitamin for day-old chicks; it is usually added to diets for the purpose of furnishing the body with labile methyl group for formation of creatine and methionine. In addition, it also assists in the prevention of hemorrhagic kidney in different animal models and perosis in turkeys and broilers (Ross et al., 2013). The deficiency of choline is normally noticed in chicks from 1-4 weeks of age. However, the rate of choline synthesis in chickens' increases in growing chicks over 8 weeks of age (Ross et al., 2013).Corbin \& Zeisel, 2012) theorized that laying hen seems to have substantial ability to synthesize choline. The latest authors found that the addition of choline to $100 \mathrm{mg} / \mathrm{kg}$ diet did not show any effect on the aspects of egg size, egg production and relative weights of albumin and yolk. Supplementation of choline at $0.4 \%$ to broiler diet improved growth traits (Ross et al., 2013). In another study by Emmert \& Baker (1997) reported that the addition of choline chloride at the rate of $2000 \mathrm{mg} / \mathrm{kg}$ to the broiler diets showed a positive effect on body weight gain of chicks. Methionine is a sulfur amino acid and it is crucial for repair, growth, and metabolism of all tissues and also for reproduction (Ross et al., 2013). The level of methionine in the animal diet is important because of the relationship with the choline needy as a methyl donor and vice versa. Choline can be supplemented in addition to methionine, but will not spare the basic methionine requirements for protein synthesis without the diet contains homo cystine (Ross et al., 2013). Pesti et al. (1981) perceived that the addition of either choline or methionine to basal diet improves growth. Some trials like Huang et al. (2015) were conducted on rats and revealed that choline insufficiency could increase the risk of getting cancer. Many kinds of literature have naked associations between choline metabolism and cancer (Kirienko et al., 2015; Marina et al., 2016). The utilization ofherb and lipotropic supplements to the feed decreases the adverse metabolicconsequences of the high-calorie diet in poultry farming (Khosravinia et al., 2015; Saeed et al., 2017). Therefore, Lcarnitine, vitamin $\mathrm{B}_{12}$, and vitamin $\mathrm{E}$ are routinely added to the poultry diet in order to reduce the liver fattening syndrome (Farrokhyan et al., 2014). The study of Jiang et al. (2014) reported that choline chloride has a lowering effect regarding cholesterol of broiler. Nowadays, the fatty liver syndrome is a metabolic disorder and it is generally encountered in the poultry industry, especially in hens kept in cage farming system. Because birds kept in cages cannot move enough to burn the calories they were taking. During egg lying, the liver, which has already become rather brittle, can easily tear. If the tears occur on large blood vessels, the bird will be susceptible to sudden death as a result of this bleeding. The present review article aimed to give more light on the structure of choline, its sources, functions, and metabolism. In addition, the current article aimed to broaden the knowledge among researchers and poultry breeder about the use of choline on a commercial level to overcome the fatty liver syndrome disorder and its repercussions that are a big threat to the poultry industry.

\section{Choline chemical structure}

Choline is a quaternary ammonium (also known as trimethyl, $\beta$ hydroxy ethyl ammonium) compound found in lipids and its molecular weight is 121.18 (Sheard \& Zeisel, 1989) as shown in Figure1.

\section{$\mathrm{CH}_{3}$}

$$
\begin{gathered}
\mid \\
\mathrm{CH}_{3}-\mathrm{N}^{+}-\mathrm{CH}_{2}-\mathrm{CH}_{2} \mathrm{OH}
\end{gathered}
$$<smiles>C=C</smiles>

\section{$\mathrm{CH}_{3}$}

Figure1: Chemical structure of choline (Sheard \& Zeisel, 1989) 


\section{Different sources and requirements of choline}

In 1849, choline was firstly isolated from ox bile (Chole in Greek). Since 1930, the nutritional significance of choline has been recognized and nowadays it's commonly dietary additive for humans and animals. Choline as chloride or sometimes as other salts like citrate is recognized as not harmful. The chief source of choline in poultry industry can be derived from the green leafy material. Moreover, the study by Song et al. (2012) reported that liver and glandular meal, fish meal and soybean meal are the richest sources of choline in poultry feedstuffs' industry. Vitamins are essential in poultry, animal and human nutrition. The requirement of these nutrients cannot be covered by the native content in feedstuffs, so extra supply is necessary to fulfill the nutrient requirements in the poultry diet (Song et al., 2012). The standard content of choline chloride in various feedstuffs based on chemical composition of crops according to NRC (1994) is given in Table 1. Normal requirement of choline in various poultry species are given in Table 2. Emmert \& Baker (1997) assessed choline bioavailability which naturally presents in peanut, soybean meal and rapeseed at rates of 83, 24 and $76 \%$, respectively. Rape seed meal has high levels of choline (6198 ppm) than those in soybean meal (2218 ppm) and peanut meal (1685 ppm).

\section{Functions and synthesis of choline}

The functions of choline are categories in four broad terms in the animal body (Zeisel \& Niculescu, 2006; Garrow, 2007).

I. Choline is important for metabolism in maintaining and building cells. In addition to, it is required for the maturation of bone cartilage matrix (Figure 2).

II. It plays a key role in the lipid metabolism in the liver. Also, choline suppresses the abnormal deposition of lipids by increasing the consumption of fatty acids or by activating its transport as lecithin in the liver (Xue \& Cui, 2001). Choline is considered as a "lipotropic" agent due to its function of acting on lipid metabolism (Corbin \& Zeisel, 2012). In the liver of broilers, adding choline (760 $\mathrm{mg} / \mathrm{kg}$ diet) reduced fat content (Rama Rao et al., 2001).

III. It is crucial for the formation of acetylcholine that plays an important role in transferring the nerve singles from presynaptic to postsynaptic fibers of sympathetic and parasympathetic nervous systems.

IV. It is considering the vital source of methyl group. It furnishes methyl group for the creation of methionine from homocysteine and of creatine from guanido acetic acid. Zeisel (1990) confirmed that a disturbance in metabolism of methionine results in alterations in metabolism of choline and vice versa. In rats, Kim et al.
Table 1 Choline chloride content in various feed ingredients

\begin{tabular}{|c|c|c|c|}
\hline \multirow[b]{2}{*}{ Feed ingredients } & \multicolumn{3}{|c|}{ Choline in ppm } \\
\hline & NRC (1984) & $\begin{array}{l}\text { NRC } \\
(1994)\end{array}$ & $\begin{array}{l}\text { IEEB } \\
(1997)\end{array}$ \\
\hline Corn & 620 & 713 & 200 \\
\hline Soybean meal (48\%) & 2731 & 3140 & 3560 \\
\hline Fat meat meal (55\%) & 2077 & 2388 & 1570 \\
\hline Corn gluten meal & 330 & 379 & 660 \\
\hline Wheat & 1002 & 1152 & 440 \\
\hline
\end{tabular}

${ }^{\mathrm{I}}$ NRC values are present in choline hydroxide; they have been converted in to choline chloride (equivalent multiply by 1.15 ), ${ }^{2}$ IEEB: (Institute European de Environment de Bordeaux, F.3300 Bordeaux): results are established on chemical analysis.

Table 2 Choline requirements in various poultry species according to NRC (1994).

\begin{tabular}{|lll|}
\hline \multicolumn{1}{|c|}{ Avian Species } & \multicolumn{1}{c|}{ Feed } & \multicolumn{1}{c|}{ Requirement } \\
\hline Broiler Chickens & & \\
\hline 0-3 weeks & Cereal grain basal diet & $1300 \mathrm{mg} / \mathrm{kg}$ of diet \\
\hline 3-6 weeks & Cereal grain basal diet & $1000 \mathrm{mg} / \mathrm{kg}$ of diet \\
\hline 6-8 weeks & Cereal grain basal diet & $750 \mathrm{mg} / \mathrm{kg}$ of diet \\
\hline Laying Hen & & \\
\hline $0-6$ weeks & Cereal grain basal diet & $1300 \mathrm{mg} / \mathrm{kg}$ of diet \\
\hline 6-12 weeks & Cereal grain basal diet & $900 \mathrm{mg} / \mathrm{kg}$ of diet \\
\hline $12-18$ weeks & Cereal grain basal diet & $500 \mathrm{mg} / \mathrm{kg}$ of diet \\
\hline Production stage & Cereal grain basal diet & $105 \mathrm{mg} / \mathrm{hen} / \mathrm{day}$ \\
\hline Turkey & & \\
\hline 0-4 weeks & Cereal grain basal diet & $1600 \mathrm{mg} / \mathrm{kg}$ of diet \\
\hline 4-8 weeks & Cereal grain basal diet & $1400 \mathrm{mg} / \mathrm{kg}$ of die \\
\hline 8-16 weeks & Cereal grain basal diet & $1100 \mathrm{mg} / \mathrm{kg}$ of diet \\
\hline $16-20$ weeks & Cereal grain basal diet & $950 \mathrm{mg} / \mathrm{kg}$ of diet \\
\hline 20-24 weeks & Cereal grain basal diet & $800 \mathrm{mg} / \mathrm{kg}$ of diet \\
\hline Breeding cycle & Cereal grain basal diet & $800-1000 \mathrm{mg} / \mathrm{kg}$ of diet \\
\hline & & \\
\hline
\end{tabular}


(1994) observed that the deficiency in folic acid may be caused secondary deficiency of choline in the liver.

V. Increasing the gain of interest for choline and its important role as a methyl donor is possibly the key factor that evaluates how rapidly a diet deficient in choline will bring pathology(Finkelstein et al., 1982). The liver can produce large amounts of betaine-homocysteine methyltransferase under the conditions of methioninedeficient, exclusively in the presence of excess betaine or choline (Emmert \& Baker, 1997)

VI. Choline may reduce the risk of hepatic and cardiovascular diseases by being available in local markets as cholineenriched eggs that are favorable needs among consumers (Krishnan, 2010).

\section{Choline metabolism pathway}

Choline is a key source of methyl group through its metabolite, which takes part in the synthesis of S-adenosyl methionine. Moreover, choline and its metabolites have many biological and physiological functions such as structural integrity, acetylcholine synthesis and signaling roles for cell membranes (Cuccurullo et al., 2017). Choline is a vital nutrient that is essential for neurotransmitter (acetylcholine) synthesis, cell membrane structure, methyl-group metabolism and signaling, and lipid transport. Phosphatidylcholine is synthesized in nucleated cells by the pathway of CDP-choline; this way used choline as the preliminary substrate, and therefore it depends on dietary level of choline. The liver is a unique organ that possesses a second pathway for phosphatidylcholine synthesis; phosphatidylethanolamine N-methyltransferase (PEMT) converts phosphatidylethanolamine (PE) to phosphatidylcholine via 3 sequential methylations using S-adenosylmethionine as the methyl donor (Gibellini \& Smith 2010). Figure 3 summarizes the metabolism of choline.

\section{Choline digestion}

Choline is generally absorbed in the jejunum and ileum parts of the intestine by sodium and an energy-dependent carrier pathway (Veth et al., 2016). After absorption, choline is transferred to the lymphatic circulation basically in lecithin form that linked to chylomicron in the phospholipids tissues (Veth et al., 2016).

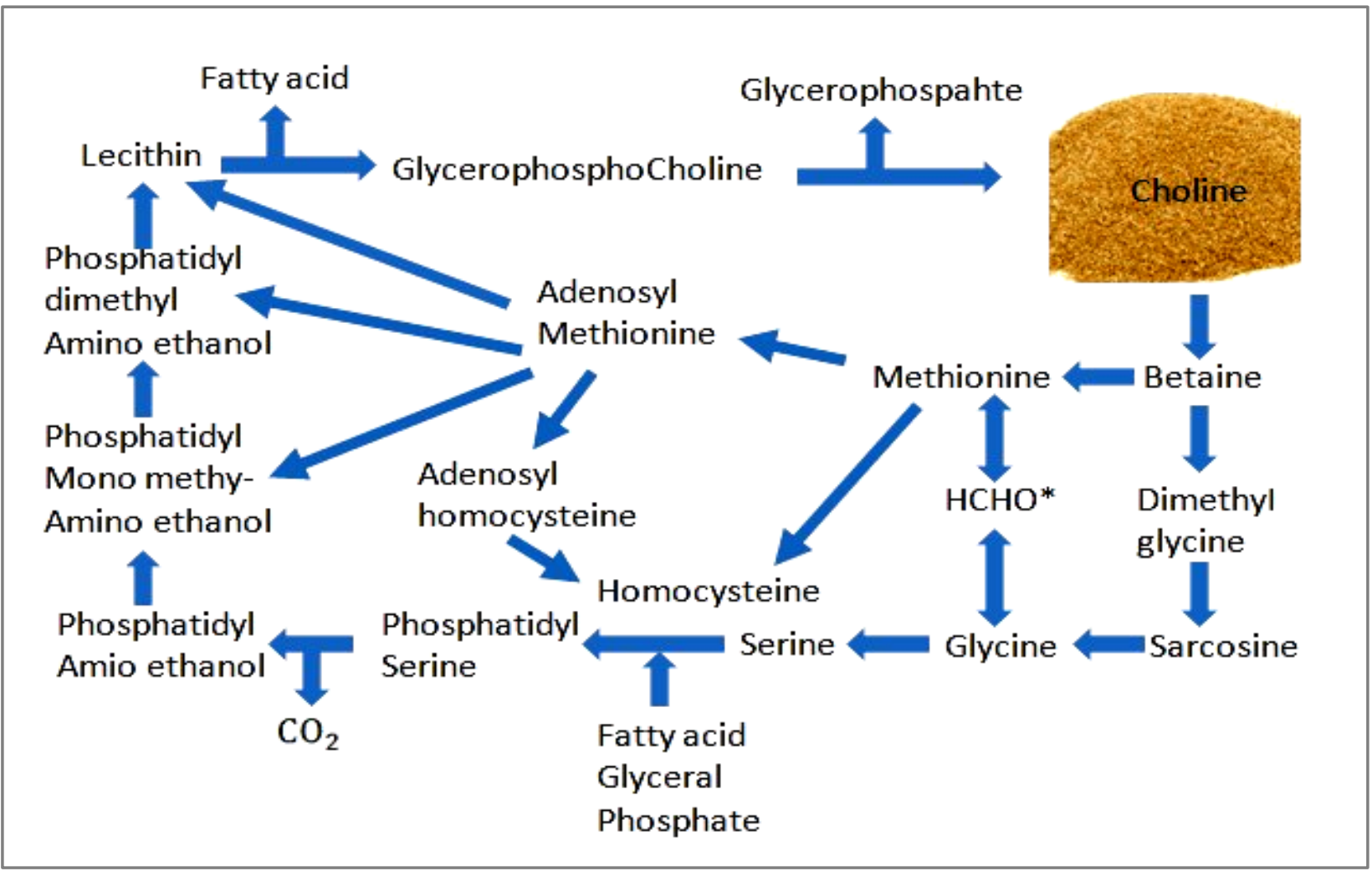

Figure 2 Synthesis and various metabolic functions of choline and related compounds.

Journal of Experimental Biology and Agriculture Science http://www.jebas.org 


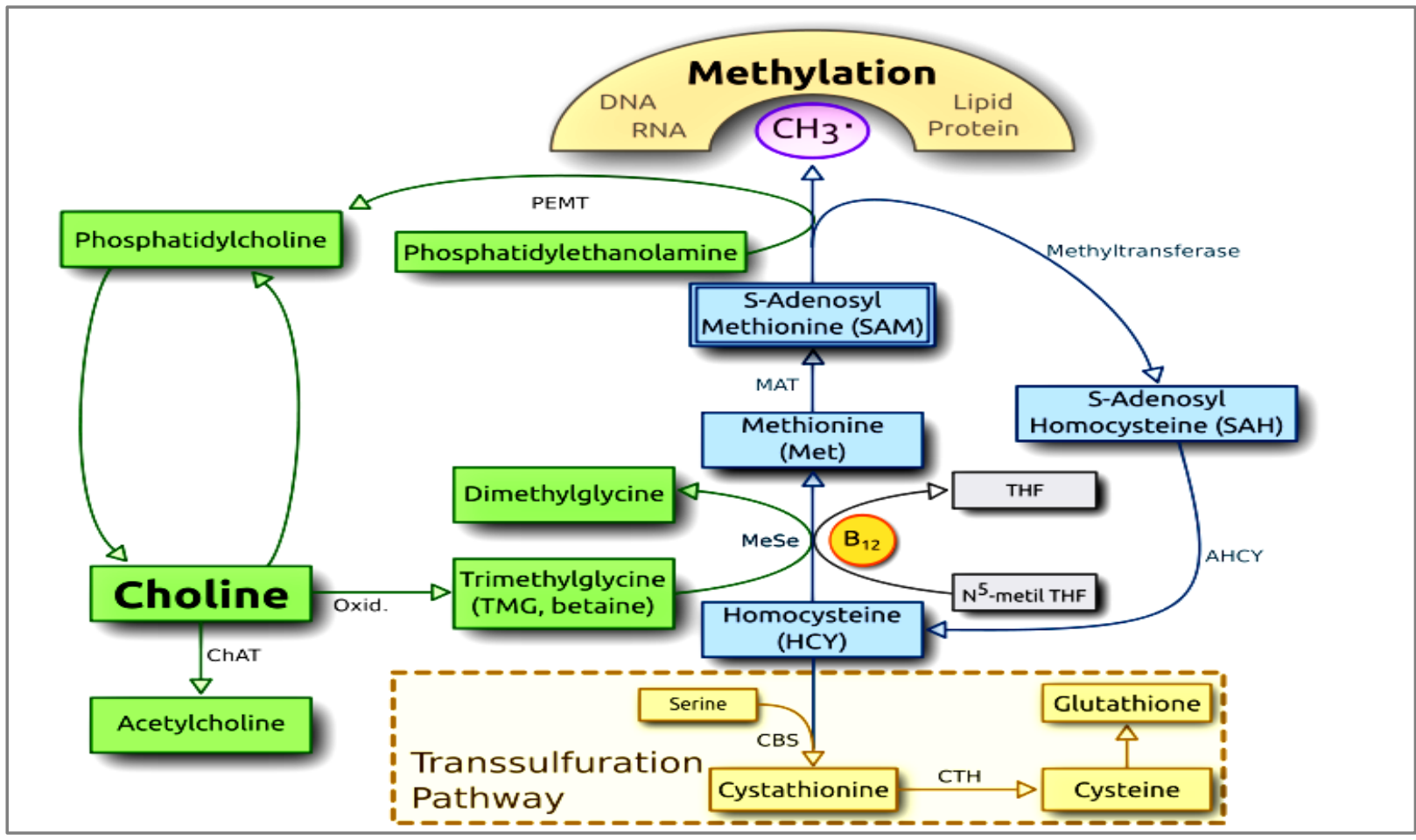

Figure 3 Choline Metabolism assessed on https://en.wikipedia.org/wiki/Choline (Gibellini \& Smith, 2010)

\section{Incredible impacts of choline}

\subsection{Choline as Antioxidant}

Choline plays an important role in multiple clinical manifestations. The function of choline as methyl is a key importance in maintaining balanced cellular antioxidant defense systems subsequently checking oxidative stress and apoptosis (Table 3).Corbin \& Zeisel (2012) illustrated the connection between choline deficiency and development of non-alcoholic fatty liver disease (NAFLD) which may finally progress to hepatocarcinogenesis. The previous study in human as well as in mice confirmed that a deletion of choline-related genes may alter mitochondrial membrane composition owing to choline deficiency. Levels of gut microbiome moderating the availability of choline might enhance the fatty liver disease. These findings established a new understanding that choline is a vital component of diet requirement and gave new insight ways in which many physiological conditions take place (Corbin \& Zeisel, 2012).

\subsection{Choline as Growth Enhancer}

Choline is an essential vitamin for the prevention of perosis as well as for growth performance of poultry species. The choline requirement as demonstrated by growth that was better gained when the diet containing $3467 \mathrm{kcal} \mathrm{ME} / \mathrm{Kg}$ diet, while the requirement for safeguard against perosis was greater to be about 1900 ppm (Fritz et al., 1967). Nesheim et al. (1971) showed that choline supplementation reduced hepatic fat content compared to control; however no improvements in weight gain for pullets fed corn-soy diet supplemented with choline during 8-20 weeks of age. Agricultural Research Council, 1975 showed that the growing poultry chicks have a requirement for choline of around $1300 \mathrm{mg} / \mathrm{kg}$ diet (ARC, 1975).

Lipstein et al. (1977) reported that the chicks that were fed choline up to 520 and $480 \mathrm{mg} / \mathrm{kg}$ in basal diets shown good responses as compared to that contained choline at the rate of 400 and 230 $\mathrm{mg} / \mathrm{kgdiet}$. Pesti et al. $(1979 ; 1980)$ reported large increases at the rate of $12 \%$ in body weight gain with supplementation of choline at 0.04 to $0.39 \%$ into the practical type diets for chicks and poults from day-old chicks up to 3 weeks of age.

Derilo \& Balnave (1980) showed that growth of broiler was reduced with the low dietary level of choline. However, these effects were highlighted by very low nutritional total sulphur amino acid (TSAA). Increased in the number of mortality and many other pathological changes that are involving in various number of tissues that were observed in birds fed on a low choline diet on the other hand, the same later authors reported that the 
Table 3 Antioxidant role of choline

\begin{tabular}{|llc|}
\hline Test system & Observed effects & References \\
\hline Male Fisher 344 rats & $\begin{array}{l}\text { Chronic methyl group deficiency due to low levels of dietary choline leads to an imbalance } \\
\text { in cellular antioxidant defence systems, increased oxidative stress, and apoptosis. }\end{array}$ & $\begin{array}{c}\text { Ossani et al., 2007; } \\
\text { Bagnyukova et al., } \\
2008\end{array}$ \\
\hline $\begin{array}{l}\text { Weanling Wistar } \\
\text { male rats }\end{array}$ & $\begin{array}{l}\text { Choline deficiency produces oxidative damage in the liver, heart, kidney, and brain, with an } \\
\text { increased lipid peroxidation of subcellular organelles and a decrease in tissue antioxidants. }\end{array}$ & Repetto et al., 2010 \\
\hline $\begin{array}{l}\text { Weanling male } \\
\text { Wistar rats }\end{array}$ & $\begin{array}{l}\text { Decreased antioxidant content and increased lipid peroxidation are earlier biochemical } \\
\text { alterations that precede and lead to histological cell death by necrosis in choline deficiency. }\end{array}$ & Schugar et al., 2013 \\
\hline $\begin{array}{l}\text { Rodent model } \\
\text { (C57BL/6J wild type } \\
\text { mice) }\end{array}$ & $\begin{array}{l}\text { Adverse effects of choline deficiency on hepatic mitochondrial structure and function could } \\
\text { be linked to the unique signature of hepatic lipid accumulation, inflammation, and cellular } \\
\text { and mitochondrial injury induced in mice maintained on a very high fat, protein-restricted, }\end{array}$ & Schugar et al., 2013 \\
\hline very low carbohydrate and ketogenic diet. & \\
\hline
\end{tabular}

high dietary concentration of choline $(1750 \mathrm{mg} / \mathrm{kg}$ feed) boost the requirement for dietary TSAA.

Neither choline nor cystine significantly affected the requirement of methionine or SAA, as estimated by body weight gain (Blachman \& Waldroup, 1980). Derilo \& Balnave (1980) obtained that when different dietary combinations of choline and TSAA were used with broiler chicks fed purified diet, maximum growth was obtained with a combination of high choline (>1750 $\mathrm{mg} / \mathrm{kg}$ ) and high TSAA (8.49/ kg diet). Anderson \& Dobson (1982) showed that increasing the amount of choline supplementation in the avian diet range from 300 to $800 \mathrm{mg} / \mathrm{kg}$ feed did not increase the performance or reduce the value of the supplementary methionine. On the other hand, Miles et al. (1983) reported better growths of chicks occurred from the concurrent addition of $0.1 \%$ potassium sulfate and $0.066 \%$ choline but larger increases were attained from the addition of $0.25 \%$ methionine, representing that both choline andsulfate may be involved in sparing methionine in turkeys birds.

The choline requirements of broiler chickens were 1300, 850 and $500 \mathrm{ppm}$ for the starter, grower and finisher periods, respectively (NRC, 1994). Parsons \& Leeper, (1984) stated that supplementation of choline or methionine improved the productive performance of laying hens. Yeo et al., (1985) suggested that chickens were given for 4 weeks a diet adequate in all nutrients except sulfur amino acid and with methionine 0.15 and $0.30 \%$ and choline 0.05 and $0.10 \%$. They reported that supplementary choline did not increase weight gain except for chickens not given methionine.

Blair et al. (1986) reported that improvement in body weights occurred by fed the chicks with dietary choline at an early stage of age, particularly in the deficiency of supplemental methionine; also, they added that an increase was more difficult to demonstrate at other age. Tillman \& Pesti (1986) found that chicks offered a feed that supplemented with L-methionine at $12 \%$ gained significantly more than those fed the basal diet, while, poultry chicks that supplemented with choline diets had gained as well as those fed L-methionine.

Andriguetto et al. (1987) studied the effect of diets based on maize meal and soybean oil meal without or with choline supplements at the rate of $200,400,600,800,1000,1200$, or 1400 $\mathrm{mg} / \mathrm{kg}$ feed from hatching until 42 days old in male and female chicks. The diets were supplemented with pyridoxine 3.00; folic acid 1.00 and cyanocobalamin $0.030 \mathrm{mg} / \mathrm{kg}$ diet. The authors found that weight gain of male and female was not significantly different among groups.

Okolelova et al. (1988) studied the influence of feeding on a basal diet plus choline chloride as liquid, or as $9 \%$ mixture with lignin or microcrystalline cellulose, or as a $43 \%$ mixture with maize cobs and found that average body weight gain at 49 days old was 1641.4, 1592.0, 1749.6 and 1677.1g, respectively. Krsmanovic et al. (1990) studied the addition of choline without or with 25 or 50 $\mathrm{g} / \mathrm{kg}$ on broiler diets and found average total body weight gain was 1862, 1867 and 1884g, respectively. Baranova, (1991) pointed out that supplementation of choline chloride in broiler diets increased body weight gain. Sonbol \& Habeeb (1991) showed that broiler chicks fed on basal grower diet up to 4 weeks of age $(22.14 \% \mathrm{CP}$ and $2810 \mathrm{kcal} \mathrm{ME} / \mathrm{Kg})$ and the basal finisher diet up to 7 weeks of age $(18.98 \% \mathrm{CP}$ and $2912 \mathrm{Kcal} \mathrm{ME} / \mathrm{Kg})$ were supplemented with $0.15 \%$ methionine $+1000 \mathrm{mg} / \mathrm{kg}$ choline. 
The addition of methionine and choline showed the highest significant live weight (1707g).

Vogt (1992) reported that growth of broiler chicks of 6-weeks old was improved by supplemented choline at levels of 200, 400, 600 and $800 \mathrm{mg} / \mathrm{kg}$ diet with corresponding addition DL-methionine atlevelsof750, 1500, 2250 and $3000 \mathrm{mg} / \mathrm{kg}$ diet, respectively. Mohamed et al., (1994) indicated that addition of choline to cornsoybean meal diets for chicks had a significantly effect on body weight gain. Ryu et al. (1995) showed that broiler chicks were fed on a basal diet supplemented with choline 0,500 and $1000 \mathrm{mg} / \mathrm{kg}$ diet. Body weight was significantly higher when supplemented choline was fed. In two experiments carried out to determine the effect of dietary choline on the performance of broiler chicks. Men-Kin et al. (1996) found that broiler chicks fed on a basal diet containing $23.5-24 \%$ CP less methionine and supplemented with choline at levels of 250,500 or $750 \mathrm{~g} / \mathrm{ton}$ in experiment 1 or at levels of 1000,1250 or $1500 \mathrm{~g} / \mathrm{ton}$ in experiment 2. Jokic et al. (2000) showed that the addition of choline to 950 and $850 \mathrm{mg} / \mathrm{kg}$ diet during the starting and finishing period, respectively with $0.20 \%$ and $0.15 \%$ methionine and 0.10 magnesium sulfate resulted in significantly $(\mathrm{P}<0.05)$ increase in body weight gain (from 6.42 to $7.41 \%$ ) and body mass of chicks from 6.31 to $7.25 \%$. Shrivastav et al. (2004) reported that choline is essential for growth and helpful to prevent leg disorder (perosis) in turkeys.

Simon et al. (1995) demonstrated that extra methionine supplementation above the recommended dose required for broilers chickens to improved their performance including body weight gain and food conversion efficiency, so choline may spare the methionine for broiler's growth (Pesti et al.,1981). Feeding a diet with choline supplementation improved body weight gain and feed efficiency in broilers either alone or in combination with methionine (Combs,1992). The study of Rama Rao et al. (2001) found that choline and methionine should be supplemented to broiler diets at higher levels to gain better results in aspects of health and production. Furthermore, Combs, (1992) postulated that choline is an absolute dietary requirement for broilers, particularly at younger ages as the chick cannot synthesize satisfactory amounts until up to 13 weeks of age. Body weight gain was improved $(\mathrm{P}<0.01)$ with increasing choline percent in the diet up to $2000 \mathrm{mg} / \mathrm{kg}$ diet, but increasing choline level-up to $2500 \mathrm{mg} / \mathrm{kg}$ diet caused a significant decrease in body weight (Sławinska et al., 2014).

\subsection{Choline as Immune Booster}

Chlorine is being considered as a member of the B-complex vitamin group and as an essential nutrient for laying hens, broilers and also for other poultry diets for the formation of the phospholipid lecithin found in egg yolk and liver (Maiorano et al., 2012). In animal nutrition, essential nutrients playing an important role on growth performance, meat quality and carcass traits (Kadam et al., 2013) and immune system development (Hhm et al., 2012). Choline showed a positive effect on immune functions by improvements in primary antibody titer of broiler chicks (Maiorano et al., 2012).

\subsection{Choline as a Potent Lipotropic Agent}

In poultry feed industry, maize is considered the main energy source. Due to non-availability of maize in many developing countries, so nutritionists are always searching for alternative energy sources for animal and poultry feeds. The replacement of maize withpearl millet or brokenrice in the diets of broilerbreeders and layer caused an accumulation of fatin the liver and abdomen. As shown in Figure 4, choline -as a lipotropic factor- has been established to fix this problem by the donation of methyl in chicken metabolism (Zeisel et al., 2003). Similarly, Rama Rao et al., (2001) reported that birds fed a diet containing choline at the level of $760 \mathrm{mg} / \mathrm{kg}$ diet significantly reduced the liver fat. So, choline must be a part of the human and animal diets (Sheard \& Zeisel 1989; Gholami et al., 2015). Therefore, it is undertaken that the supplementation of choline in poultry feed can alter the deposition of fat and also the hatching and laying performance of broiler breeders that fed on different sources of energy.

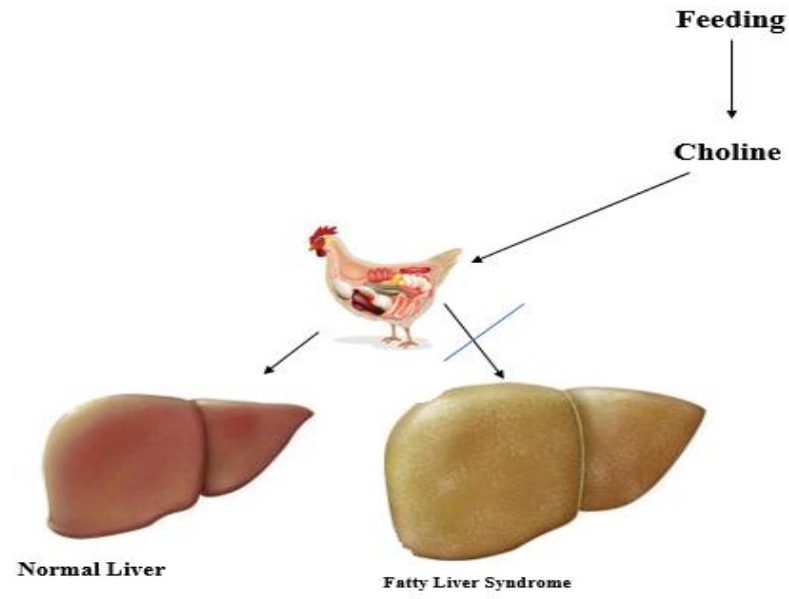

Figure 4 Effect of choline against fatty liver syndrome

\section{Conclusion}

From the aforementioned information, it could be concluded that choline has main three vital metabolic functions that relate to its structural integrity of cell membranes, a lipotropic mediator in fat metabolism in liver and also act as a precursor for acetylcholine synthesis that known as neurotransmitter agent for nerve impulses. So choline can be considered as a powerful lipotropic agent that would play an important role in fat metabolism by 
removing deposition of fat in the liver or ganand consequently prevents fatty liver disorder. So, these vital properties highly recommend the use of choline as commercially feed additive to cope with the metabolic disorders and enhance bird's health and productivity.

\section{Acknowledgment:}

All the authors of the manuscript thank and acknowledge their respective Universities and Institutes

\section{Conflict of interest}

Authors have no conflict of interest.

\section{References}

Agricultural Research Council "ARC" (1975) Nutrient requirements of farm livestock No 1 poultry, $2^{\text {nd }} \mathrm{Ed}-$ London, Her Majestry s stationery office

Alagawany M, El-Hack MEA, Arif M, Ashour EA (2016) Individual and combined effects of crude protein, methionine, and probiotic levels on laying hen productive performance and nitrogen pollution in the manure. Environmental Science \& Pollution Research 23: 18.DOI:10.1007/s11356-016-7511-6.

Anderson JO, Dobson DC (1982) Comparison of dl-methionine and its sodium salt in water solution in broiler starter diets with two choline levels. Poultry Science 61: 2288-90.DOI/10.3382/ps.0612288.

Andriguetto JML, Perly MJ, Dutra JS, Flemming I, Minardi AGDE, Souza AG, Emael JL, Andiguetto SG, Franco (1987) Evaluation of amount of supplementary choline for meatchickens. Arquivous de Biologia Technologia 30: 501-505.

Bagnyukova TV, Powell CL, Pavliv O, Tryndyak VP, Pogribny IP (2008) Induction of oxidative stress and DNA damage in rat brain by a folate/methyl-deficient diet. Brain Research 1237: 44-51.doi: 10.1016/j.brainres.

Baranova G (1991) Choline in diets for broiler chickens. Ptitsevodstvo 9: $15-17$.

Biswas S, Giri S (2015) Importance of choline as an essential nutrient and its role in the prevention of various toxicities. Prague Medical Report 116: 5.DOI: $10.14712 / 23362936.2015 .40$.

Blackman J R, Waldroup PW (1980) Influence of monensin, sodium sulfate, choline, and cystine on the methionine requirement of young broiler chicks. Poultry Science 59:1558-1558

Blair ME, Potter LM, Bliss BA, Shelton JR (1986) Methionine, choline, and sulfate supplementation of practical-type diets for young turkeys. Poultry Science 65: 130-137.DoI.org/10.3382/ps.0650130.

Combs GF, Jr (1992) The vitamins. Fundamental aspects of nutrition and health.Academic Press, San Diego, California.

Corbin KD, Zeisel SH (2012) Choline metabolism provides novel insights into nonalcoholic fatty liver disease and its progression. Current Opinion in $\quad$ Gastroenterology 28: 159.DOI: 10.1097/MOG.0b013e32834e7b4b.

Journal of Experimental Biology and Agriculture Science http://www.jebas.org
Cuccurullo V, Stasio GD D, Evangelista L, Castoria G, Mansi L (2017) Biochemical and pathophysiological premises to positron emission tomography with choline radiotracers. Journal of Cellular Physiology 232: 270-275.DOI: $10.1002 /$ jcp. 25478.

Derilo YL, Balnave D (1980) The choline and sulfur amino acid requirements of broiler chickens fed on semi-purified diets. British Poultry Science 21: 479-487.doi.org/10.1080/00071668008416700.

Emmert JL, Baker DH (1997) Choline bioavailability assessment of oilseed meals in chicks. Proceedings of the Federation of American Societies for Experimental Biology 11: 11: 745-752.

Farrokhyan P, Bouyeh M, Lartey FM, Seidavi A (2014) The effects of dietary 1-carnitine and gemfibrozil on performance, carcass characteristics, cholesterol and triglycerides in broiler chicks. Avian Biology Research 7:160-166.DOI: 10.3184/175815514X14067215301247.

Finkelstein JD, Martin JJ, Harris BJ, Kyle WE (1982) Regulation of the betaine content of rat liver, Archives of Biochemistry \& Biophysics 218: 169-73.

Fritz JC, Roberts T, Boehne JW (1967) The chick's response to choline and its application to an assay for choline in feedstuffs. Poultry Science 46:1447-54.https://doi.org/10.3382/ps.0461447.

Garrow TA (2007) "Choline." In Handbook of Vitamins, Fourth Edition. CRC Press.

Gholami J, Qotbi AA A, Seidavi A, Meluzzi A, Tavaniello S, Maiorano G (2015) Effects of in ovo administration of betaine and choline on hatchability results, growth and carcass characteristics and immune response of broiler chickens. Italian Journal of Animal Science14.DOI.org/10.4081/ijas.2015.3694.

Gibellini F, Smith TK (2010) Thekennedy pathway--de novo synthesis of phosphatidylethanolamine and phosphatidylcholine. IUBMB Life. 62:414.DOI: 10.1002/iub.337.

Hhm H, Ismaeil Z, Yakout H (2012) Influence of acetyl choline level on productive performance and immune responses in broiler chicks. Egyptian Journal of Animal Production 49: 37-43.

Huang Z, Rui J, Li X, Meng X, Liu Q (2015) Use of ${ }^{11}$ C-Choline positron emission tomography/computed tomography to investigate the mechanism of choline metabolism in lung cancer. Molecular Medicine Reports 11: 3285-3290.doi:10.3892/mmr.2015.3200.

IEEB (1997) Institute European de Environment de Bordeaux, F.3300 Bordeaux.

Jiang X, West AA, Caudill MA (2014) Maternal choline supplementation: a nutritional approach for improving offspring health. Trends in Endocrinology \& Metabolism 25: 263-73. doi: 10.1016/j.tem.2014.02.001.

Jokic Z, Hristov S, Đorđevic, N (2000) Influence of supplemental methionine, choline and magnesium-sulfate in the diet on daily gain weight and efficiency of feed consumption of broiler chickens. Veterinarski Glasnik 29-38.

Kadam MM, Bhuiyan MM, Islam F, Iji PA (2013) Evaluation of betaine as an in ovo feeding nutrient for broiler chickens. Proceeding of $24^{\text {th }}$ Australian Poultry Science Symposium, Sydney, Australia, Pp 158.

Khosravinia H, Chethen, PS, Ukmakantha B. Nourmohamadi R (2015) Effects of lipotropic products on productive performance, liver lipid and enzymes activity in broiler chickens. Poultry Science Journal 3: 113-120. 
Kim YI, Miller JW, da Costa KA, Nadeau M, Smith D, Selhub J, Zeisel SH, Mason JB (1994) Severe folate deficiency causes secondary depletion of choline and phosphocholine in rat liver. Journal of Nutrition 124: 2197.

Kirienko M, Sollini M, Lopci E, Versari A, Chiti A (2015) Applications of pet imaging with radiolabelled choline (11c/18f-choline). The quarterly journal of nuclear medicine and molecular imaging: official publication of the Italian Association of Nuclear Medicine (AIMN) [and] the International Association of Radiopharmacology (IAR), [and] Section of the Society of Radiopharmaceutical 59:83-94.

Krishnan RP (2010) "Effects of dietary choline, folic acid and vitamin B 12 on laying hen performance, egg components and egg phospholipid composition." Available on https://core.ac.uk/display/17240556 accessed on 24th April, 2017.

Krsmanovic M, Huskic L, Tešovic Z (1990) Choline in the nutrition of broilers. Praxis Veterinaria 159-169.

Lipstein B , Bornstein S, Budowski P(1977) Utilization of choline from crude soybean lecithin by chicks. Growth prevention of perosis. Poultry Science 56:332-336. doi.org/10.3382/ps.0560331.

Maiorano G, Sobolewska A, Cianciullo D, Walasik K, Elminowskawenda G, Sławińska A (2012) Influence of in ovo prebiotic and synbiotic administration on meat quality of broiler chickens. Poultry Science 91: 2963-9.doi.org/10.3382/ps.2012-02208.

Marina B, Anna G, Roberta N, Balaji K, Bhujwalla ZM , Rossella C (2016) Choline metabolism alteration: a focus on ovarian cancer. Frontiers in Oncology 6.Doi: 10.3389/fonc.2016.00153.

Men-Kin-VK, Agal-Tsova TM, Podkelzina (1996) Effect of choline chloride on growth, vitamin An available and biochemical values of blood in broiler chicks fed on a diet low in methionine. Izvestiya-TimiryaZevskoisel Skokhozaistvennoi- Akademii 3: 173-181.

Miles RD, Ruiz N, Harms RH (1983) The interrelationships between methionine, choline, and sulfate in turkey diets. Proceedings of the Society for Experimental Biology Biology \& Medicine 173: $32-4$

\& Medicine Society for Experimental

Mohamed MA, EL-Sherbiny AE, Hamza AS, Motawe HFA (1994) Biological evaluation of the protein quality of full fat rape seed meal for chicks. Journal of Agricultural Sciences, Mansoura University 19: 523.

Nesheim MC, Norvell MJ, Ceballos E, Jr LR (1971) The effect of choline supplementation of diets for growing pullets and laying hens. Poultry Science 50: 820.doi.org/10.3382/ps.0500820.

NRC (1984) Nutrient requirement for poultry, $8^{\text {th }}$ revised edition. Subcommittee on Poultry Nutrition, National Research Council. National Academy Press Washington D.C. United States of America.

NRC (1994) Nutrient requirement for poultry, $9^{\text {th }}$ revised edition. Subcommittee on Poultry Nutrition, National Research Council.National Academy Press Washington D.C. United States of America.

Okolelova T, Spirina S, Kureneva V (1988) Dried froms of choline chloride. Ptitsevodstvo 8: 26-27.

Ossani G, Dalghi M, Repetto M (2007). Oxidative damage lipid peroxidation in the kidney of choline-deficient rats. Frontiers in Bioscience A Journal \& Virtual Library 12: 1174.

Parsons CM, Leeper, RW (1984). Choline and methionine supplementation of layer diets varying in protein content. Poultry Science 63: 1604-9.

Pesti GM, Benevenga NJ, Harper AE, Sunde ML (1981) The effects of high dietary protein and nitrogen levels on the preformed methyl group requirement and methionine-induced growth depression in chicks. Poultry Science 60: 425 .

Pesti GM, Harper AE, Sunde M L (1979) Sulfur amino acid and methyl donor status of corn-soy diets fed to starting broiler chicks and turkey poults. Poultry Science 58: 1541-1547. doi.org/10.3382/ps.0581541.

Pesti GM, Harper AE, Sunde M L (1980) Choline/methionine nutrition of starting broiler chicks. Three models for estimating the choline requirement with economic considerations. Poultry Science 59: 107381.doi.org/10.3382/ps.0591073.

Rama Rao SV, Sunder GS, Reddy MR, Praharaj NK, Raju MV, Panda AK (2001) Effect of supplementary choline on the performance of broiler breeders fed on different energy sources. British Poultry Science 42:362. DOI:10.1080/00071660120055340.

Repetto MG, Ossani G, Monserrat AJ, Boveris A (2010) Oxidative damage: the biochemical mechanism of cellular injury and necrosis in choline deficiency. Experimental \& Molecular Pathology 88:143.

Ross RG, Hunter SK, Mccarthy L, Beuler J, Hutchison AK, Wagner BD (2013) Perinatal choline effects on neonatal pathophysiology related to later schizophrenia risk. American Journal of Psychiatry 170: 290-8. DOI: 10.1176/appi.ajp.2012.12070940.

Ryu KS, Roberson KD, Pesti GM, Eitenmiller RR (1995) The folic acid requirements of starting broiler chicks fed diets based on practical ingredients. 1. Interrelationships with dietary choline. Poultry Science 74:1447-55.doi.org/10.3382/ps.0741456.

Saeed M, Yatao X, Ur Rehman Z, Asif Arain M, Nawaz Soom R, Abd ElHac ME, Ahmed Bhut, Z, Abbasi B, Dhama K, Sarwar M A Chao S (2017) Nutritional and healthical aspects of yacon (smallanthussonchifolius) for human, animals, and poultry. International Journal of Pharmacology 13: 361-369. DOI: 10.3923/ijp.2017.361.369

Schugar RC, Huang X, Moll AR, Brunt EM, Crawford PA (2013) Role of choline deficiency in the fatty liver phenotype of mice fed a low protein, very low carbohydrate ketogenic diet. PLoS One 8: 1016-1020.

Sheard NF, Zeisel SH (1989) Choline: an essential dietary nutrient. Nutrition 5: 1-5.

Shrivastav AK, Dash BB, Johri TS (2004) Effect of dietary levels of choline in relation to sulphur amino acid for growth and immune response in quail broilers. Indian Journal of Poultry Science 39: 9-14.

Simon A, Bergner H, Van DB (1995) methodical investigations on the metabolism oriented determination of methionine requirement of broiler chickens. 3. degradation of $14 \mathrm{c}-(\mathrm{ch} 3)$ - and 35s-methionine after feeding of synthetic diets]. ArchivFürTierernährung 47: 229.

Sławinska A, Siwek MZ, Bednarczyk MF (2014) Effects of synbiotics injected in ovo on the regulation of immune-related gene expression in adult chickens. Transplantation 75: 997.

Sonbol SM, Habeeb A (1991) Effect of dietary energy, methionine, choline and sulfate levels on productive performance and some blood constituents of broiler chicks during the growing periods. Egyptian Journal of Basic and Applied Sciences 310-328. 
Song G, Cui Y, Han ZJ, Xia HF, Ma X (2012) Withdrawn: effects of choline on sodium arsenite-induced neural tube defects in chick embryos. Food \& Chemical Toxicology An International Journal Published for the British Industrial Biological Research Association 50: 4364-74.DOI:10.1016/j.fct.2011.06.009.

Tillman PB, Pesti GM (1986) The response of male broiler chicks to a corn-soy diet supplemented with 1-methionine, 1-cystine, choline, sulfate, and vitamin b12. Poultry Science 65:1741-8.

Veth MJD, Artegoitia VM, Campagna SR, Lapierre H, Harte F, Girard CL (2016) Choline absorption and evaluation of bioavailability markers when supplementing choline to lactating dairy cows. Journal of Dairy Science 99: 9732-9744. doi: 10.3168/jds.2016-11382.

Vogt-H, (1992) can methionine be partially replaced with choline in broiler diets. Landbauforschung-volkenrode 42: 141-145.
Xue M, Cui Y (2001) Effect of several feeding stimulants on diet preference by juvenile gibel carp (carassiusauratusgibelio ), fed diets with or without partial replacement of fish meal by meat and bone meal. Aquaculture 198: 281-292.doi.10.1016/S0044-8486 (00)00602-5.

Yeo TH, Han IK, Palk IK (1985)The choline-methionine interrelationship in the growing broiler chicks. Korean Journal of Animal Science 27:663 666.

Zeisel SH (1990) Choline deficiency. Journal of Nutritional Biochemistry 1:332-349.

Zeisel SH, Mar MH, Howe JC, Holden JM (2003) Concentrations of choline-containing compounds and betaine in common foods. Journal of Nutrition, 133:1302-7.

Zeisel SH, Niculescu MD (2006) Perinatal choline influences brain structure and function. Nutrition Reviews 64: 197-203. 